\title{
The "Galamsey" Menace: Implications on the archaeological record at Awudua Dada, Western Region, Ghana
}

\author{
Fritz Biveridge \\ Senior Lecturer \\ Department of Archaeology and Heritage Studies \\ University of Ghana, Legon \\ Email: fbiveridge@ug.edu.gh
}

\begin{abstract}
This article discusses the socio-cultural consequences of small-scale artisanal gold mining on the archaeological record and other heritage resources at Awudua Dada, located in the Prestia-Huni Valley District of the Western Region, Ghana. The settlement witnessed vibrant commercial exchanges between Wassa and Dutch traders in the mid-seventeenth century because of its abundant gold resources, much of which was exchanged for novel European trade goods such as varieties of alcoholic beverages, guns, gunpowder, and finished metal products among many others. Currently abandoned and desolate, groups of small-scale artisanal gold miners continue to prospect gold there, and along the banks and bed of the Ankobra River which lies close-by. Archaeological, historical, and ethno historical research constituted the principal methods used to derive data for the study which revealed that mining had not only negatively impacted the archaeological record and other cultural resources there but had also caused significant environmental degradation.
\end{abstract}

Keywords: Small-scale artisanal gold mining, archaeological record, excavations, cultural materials, surface surveys, galamsey 


\section{Introduction}

There is a dearth of information from an archaeological perspective on the socio-cultural impact of unlicensed smallscale artisanal gold mining on the archaeological record and other cultural heritage resources in Ghana. To-date, much of the literature on small-scale artisanal gold mining significantly focused and dealt with its effect on the natural environment (including aquatic bodies), local subsistence and livelihoods. This article thus, contributes to filling the lacuna in the literature, especially as it pertains to the archaeological record. The term archaeological record refers to all cultural materials made and used by ancient societies which are recovered, analysed, and interpreted for purposes of reconstructing their past technological and socio-cultural lifeways.

In Ghana, unlicensed small-scale artisanal gold miners are called "galamseyers" and their operations are termed "galamsey," derived from the phrase "gather them and sell". Though illegal and punishable with heavy fines and/or long jail terms, the activity still persists in many parts of the country, and is a popular vocation choice for many youths in Ghana's informal economic sector. Studies by Zindzy (2018) estimates the current "galamseyer" population to between 20,000 and 50,000, and attributes the high numbers to the current high unemployment level and lack of job security for most youths in southern Ghana where the activity is most rife. Research by Mantey et al (2017) also indicates that most "galamseyers" suffer from the effects of mercury poisoning in later life. This is because unlike their counterpart miners working with the large established firms, they use a variety of crude processing methods to find gold in free metallic dust form. Others also process oxide and sulphide gold ores using liquid mercury (Amankwa and Sackey, 2003).

\section{The research area and research methodology}

The locus of the archaeological investigation was Awudua Dada (GPS coordinates $05^{\circ} 22^{\prime} 32 \mathrm{~N}^{\prime \prime} 002^{\circ} 08^{\prime} 05^{\prime \prime}$ 
W). This ancient settlement lies in the heart of the TarkwaPrestia-Bogoso-Aboso-Nsuta axis, in the Western Region where much of Ghana's gold and other mineralization resources occur. In 1922, the indigenes voluntarily migrated en-mass to new grounds, near the newly built Tarkwa-Prestea railway line. They named their new settlement Awudua, after their ancestral homeland - Awudua Dada (dada in Twi means old). Economic considerations, namely, to facilitate easy transportation of their farm produce to markets, many of which lay along the new railline constituted the raison d'etre for the relocation. The settlement remained abandoned for almost seven decades till the late 1990's when it was reoccupied by small unlicensed artisanal miner groups, mostly migrants of non Wassa descent. The purpose was to rework the abandoned gold pits which were rumoured to still hold considerable reserves of gold. These miners still occupy the settlement and are responsible for the extensive physical and chemical degradation found there. Large portions of the original settlement quarter remain desolate, covered in many places with thick patches of overgrown thickets and bushes, and except for the several uncovered pits, soil heaps, and scatters of cultural materials overlying the grounds, it would appear to any firsttime visitor that it had never been occupied.

Awudua Dada and its co-terminus was selected for investigation because it has a long checkered history of traditional gold mining, pre-dating the arrival of the Dutch in 1653. According to Nana Kwabena Oboh II (pers. com. 2018), the Okyeame (chief linguist) of Awudua, in the olden days, after heavy rains, the indigenes picked-up small gold nuggets from the ground. Awudua Dada was a major source of gold for the Dutch West India Company (WIC), and other European traders and interloper on the Gold Coast (now Ghana) during the Atlantic contact period. Fort Ruychaver, one of only two early European trade stations to be sited in Ghana's forested interior is also located there, along the banks of the Ankobra River which lies east of it. The settlement's underlying stratigraphy contains 
a rich corpus of cultural remains spanning over four centuries which if analyzed can facilitate chronological sequencing and reconstruction of Ghana-Dutch relations, and past cultural lifeways of the indigenous Wassa population that settled the site in the remote past. The archaeological relevance of Awudua Dada for such a topical study therefore cannot be over-emphasized.

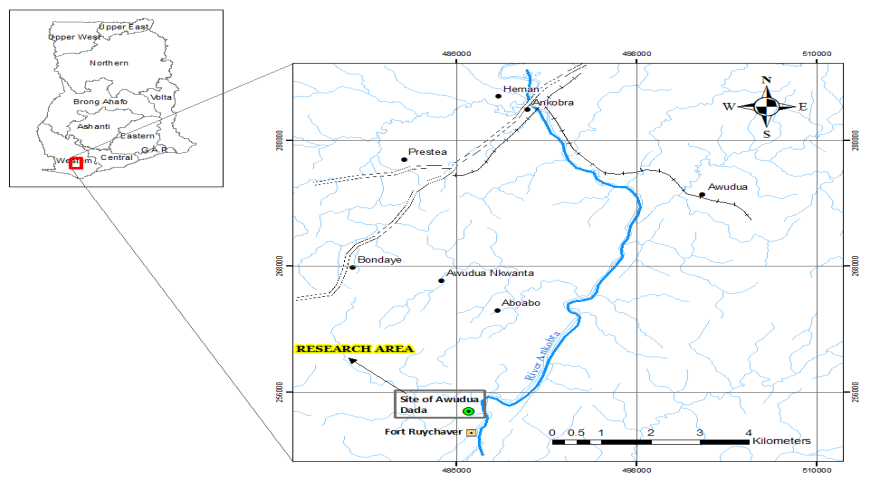

Fig 1. Map of Awudua Dada and its neighbourhoods (Source: Merrick Posnansky, 1976, p.12)

Data derived from archaeological investigations conducted at Awudua Dada constituted the primary data source used to undertake the study. Other equally important source materials used comprised historical data and ethno-historical narratives. Recourse to archaeological investigations was necessary to retrieve material remains from the archaeological record. Much of the historical data are archived at the State Archives (The Hague) and Balme Library, University of Ghana. The bulk comprised old WIC ship manifests, letters, and diaries of former WIC officials on the Gold Coast. Other historical documents perused included commercial transactional reports 
by interloper captains and traders; many of whom interacted with the natives during the Atlantic contact period (1471-1880). The ethno-historical data was derived from a sample universe of 45 indigenous respondents (39 males and 6 females), all residing at Awudua. They included two clan elders, a sub-chief, the chief linguist of Awudua (Okyeame), a traditional priest, and 29 artisanal miners found prospecting gold at Awudua Dada. The ages of the respondents ranged from 39 - 94 years.

\section{Historical background of Awudua Dada}

Several early Dutch records referred to Awudua Dada as Abaqua and Dubaqua (Bosman, 1705; Barbot, 1732). It is unknown when it was first occupied. What is known from ethnohistorical narratives of the people of Awudua and WIC records is that it was settled by the Wassa people before the Dutch arrival there in 1653. A year prior to this, Captain Jacob Ruychaver, the Director-General of the WIC had dispatched his deputy Jacob Valckenburg inland from Elmina, to locate Awudua Dada. The purpose of Valckenburg's mission was to verify whether the large quantum of gold traded on the coast, and rumoured to be mined at Awudua Dada was veracious. Captain Ruychaver had three long term goals: the first was to directly secure for the Dutch the goldmines of Awudua Dada. The second was to eliminate all the local middlemen engaged in the local gold trade; and the third was to control all the principal overland trade routes used by these middlemen to reach the coast (Dantzig, 1973, 1980; Doortmont, 2013). Valckenburg reported on his return that there was bustling trade in gold at Awudua Dada, involving several Axim traders, bartering locally produced salt for Awudua Dada gold. He also reported that the area was littered with hundreds of uncovered old and recently opened and uncovered gold prospecting pits (Dantzig, 1980; Delpino, 2013). Valckenburg's report galvanized Captain Ruychaver to hurriedly dispatch another team to Awudua Dada in 1654, this time to build a trade post which was completed in a record six months and named Fort Ruychaver. 
Captain Ruychaver figured that securing permanent residency there would guarantee the success of his three goal plan.

Records of the WIC posit that Captain Ruychaver's plan initially paid-off because the subsequent five years witnessed vibrant commercial exchanges between the Dutch and Wassa (Dantzig, 1973, 1980; Posnansky and Dantzig, 1976). Large quantities of Awudua Dada gold was transported to notable Dutch-owned trade factories like Elmina Castle, and Forts Battenstein and Eliza Carthago on the coast; and exchanged for novel Dutch imports like guns, varieties of liquors, gunpowder, finished metal products, tobacco, and Venetian and Bohemian glass beads (Dantzig, 1973; Claridge, 1972; Delpini, 2013; Doortmont, 2013; Anquandah, 1999). Records of the WIC also indicated that the trade developed and became very lucrative, requiring the construction of two palisades and the erection of three canons in 1656, primarily to fortify the fort and secure the Dutch trade there in the event of an attack from the natives and/ or other European competitors who may attempt to take over the fort and the trade there.

Incidentally this profitable venture was truncated in 1659, following a bitter misunderstanding between Antonie de Liefde (also called Jan de Mancke, "the cripple"), the Dutch Factor of the fort and one Janty, a local Caboceer from Adom Kingdom over a debt owed the former by the latter. The incident initially culminated in a minor shoot-out between the two groups but worsened to become a bitter conflagrated encounter. Antonie de Liefde was reported to have run-out of ammunition during the course of the battle that ensued, and fearing he would be captured and tortured, set fire to the fort's small armory completely blowing-up and leveling the fort and the native houses nearby. The explosion is reported to have killed over eighty of the locals and three officials of Company including Antonie de Liefde. His deputy and six of the fort's slaves however, managed to escape and reported the incident to the Dutch Governor headquartered at Elmina Castle. Nana 
Kwabena Aboh 11 (pers. com. 2018) informed the author that a thick forested grove located some 40 metres northwest of where Fort Ruychaver once stood, and currently barred to the public is the burial place of the 80 natives who perished in the Antonie de Liefde-Janty battle. Notable vestiges of this early Dutch-Wassa exchange network include the ruined stone foundations of Fort Ruychaver, veritable scatters of imported Dutch red roofing tiles used to roof the fort, and several partly covered ancient gold prospecting pits.

\section{Pre-colonial gold mining at Awudua Dada}

Prior to the arrival of the Portuguese in 1471, native miners in the Gold Coast forested interior were winning and exporting significant quantities of gold, via several overland routes to polities on the coast, the Sahel, and the Sahara (Burton, 1863; Arhin, 1978; Anquandah, 1982). The Italian trader Benedetto Dei from Geno for example, observed during one of his visits to Timbuktu that the collars of guard dogs belonging to the king were profusely decorated with gold. According to van Dantzig (1980), considerable quantities of the gold imported from the Gold Coast hinterland was re-exported to the Mediterranean, the Iberian Peninsula, and the Caliphate of Cordoba Region in Europe. Other notable commodities from the forest belt linked to this north-south directional trade network included kola nuts, animal skins, salt, and finished metal tools. Along the coast, the Portuguese were captivated with the abundant gold jewelries that bedecked the bodies of the various ethno-linguistic populations settled there, some of which was sourced from the interior (van Dantzig, 1980, p. 3; Hinson, 2005; DeCorse, 2001, p. 23). It was therefore not surprising that Europeans fittingly named the region the Gold Coast, after its abundant gold resources. Some scholars, notably Ofosu-Mensah (2017[a]), Agbesinyale (2003), and Boahen (1980) have argued that it constituted the major reason for its subsequent colonization by the British in the nineteenth century. 
Except for traditional groves, shrines, and sacred places which were strictly barred, miners could win gold anywhere in the research area in pre-colonial times. This was because the traditional belief among the Wassa peoples of the research area was that gold and all activities associated with its mining were directly associated with asaase yaa (the earth god), their ancestors, and other spirit beings (Romer, 1964; Dumett, 1998). The pouring of libation, invocatory prayers, spiritual appropriation rites, and sacrificial appeasements, sometimes involving "offerings" of live animals and occasionally otor (mashed yam, palm oil and eggs) were thus, a necessary prerequisite offering to these revered "spirits" before prospecting and mining could begin.

Similar rituals involving "thanksgiving" rites were also performed when miners discovered rich gold deposits. The purpose was to appease the "spirits" and prevent them from "moving" the gold to another location. Several taboos were also associated with traditional small-scale artisanal gold mining in the research area in the past. For example, it was taboo for menstruating women to pan gold in the Ankobra River and working in pits being prospected for gold. Offenders were oftentimes, publicly punished and/or had to undergo specific "cleansing" rites before being allowed back to the community.

Three traditional methods were employed by the people of Awudua Dada to exploit gold during the pre-colonial period (Daaku, 1970; Arhin, 1978; Dumett, 1987, 1998; and Ofosu-Mensah, 2014, 2017[b]). The first which was relatively uncommon applied to regions with abundant reserves of gold at the upper levels of the stratigraphy. No digging was involved, and small nuggets of gold became visible inside gullies, ditches, and along the surface of village streets after downpours to be collected (Storsveen, 2010, p. 143; and DeCorse, 2001, p. 143). Such "promising areas" were marked out for prospecting after the finder had reported it to the Cabucer (Carstensen, 1842). It followed therefore that much of the activities involving the 
first method was undertaken seasonally, in the main wet season which was between mid-April to late June, and the minor wet season which was between September to mid-November, when the ground had been dampened and soft rocks holding gold had loosened.

The second method was common to populations settled along the banks of rivers and rivulets and was because it required large volumes of clean water to successfully execute. The first stage involved scooping and panning gold bearing alluvium and crushed pebbles recovered from riverbeds. The second stage involved skilfully whirling soil in soft circular motions in rounded metal basins and calabashes repeatedly, to gradually wash away the clay and sand leaving tiny pecks of gold dust and nuggets at the base of the basin. Locally made pans, shovels, pick axes, and manual sluice boards constituted other tools used to undertake this activity. Where the ores were embedded in underwater rocks, the rocks were recovered and brought to the banks to be crushed to access the gold within. In the past, the process did not involve the use of environmentally harmful chemicals such as cyanide and mercury to extract gold as is the case in the research area currently. The process however was arduous and required patience, and it generally took several years of practice to master the craft and become adept and thoroughly proficient.

Despite the technological simplicity of this method, several early European scholars intimated that significant recoveries, sometimes in the form of nuggets weighing as much as 8 ounces, could be extracted per miner daily (Romer, 1964). Pre-colonial miners using this method oftentimes, looked out for ferns, and at the roots of trees recently felled by rainstorms for signs of the shiny metal which they had learnt from experience were common cues for discovering rich gold bearing deposits. Other veritable signs of auriferous strata included "a layer of "grey clay" along river beds and banks underlying a surface layer of "yellow clay" (Ofosu-Mensah, 2017[b], p. 42). 
The third and commonest method to win gold involved the digging of small, rounded pits to recover gold bearing rocks which were crushed and washed to obtain gold. Unlike method one, this method was a dry season endeavour, when the water table at most places was low and the possibility of pits being flooded was unlikely. The dry season also coincided with the period when demand for farmhands was low. According to prospectors using this method, they were oftentimes "guided by plants and rock formations found in gold bearing areas. Valuable formation of vein gold might be discovered by recognizing particular types of vegetation which they knew from experience to lie above auriferous gravels" (Ofosu-Mensah, 2017[a], p. 42). Where gold bearing rocks run horizontally, long trenches were dug along the rock paths to recover the gold.

The standard depths of gold prospecting pits during the pre-colonial period were averagely between 6.09 metres and 9.44 metres below ground surface (Ofosu-Mensah, 2009 and 2014). Research by Rodney (1969) however, has shown that in exceptional cases, pits dug by small-scale artisanal miners could extend beyond 30.48 metres. The gold prospecting pits at Awudua Dada were connected to the base by hollow steps cut into the pit's lateral sides at about one foot intervals. This technique facilitated ascent from the base to ground surface, and descent from ground surface to the base of the pits. Sometimes, movement inside the pits were also effected by means of two or more tightly twisted vegetal ropes. Twisting was done to give the rope added strength to safely hold in mid-air the full weight of an adult (Jenkins, 1972). To prevent the sides and roofs overhanging the pits from caving in, tree trunks sawn to the required beam sizes were used as support shafts. According to Storsyeen (2010), several of the vertical pits were sometimes simultaneously inter-connected horizontally via tunnels as more of the gold bearing veins were discovered and the ores dug out. Miners also sometimes out-opened these inter-connected lateral units into rounded chambers at the bottom to allow inflow of 
fresh air into the pits.

Gold mining at Awudua Dada was exclusively a male reserved vocation in the past (Burton, 1883). Occasionally, women assisted their male counterparts by undertaking less strenuous duties like scooping small pockets of alluvium from the riverbed and carry gold bearing rocks from pits to nearby grounding sites to be crushed into tiny particles. The dominant operational work-force comprised only close-knit family members, with occasional assistance coming from the extended family, house-hold slaves, and close community acquaintances. This was done purposely to guard and keep within the working group valuable information relating to quantum of gold in the group's custody, and their operational locations (Dumett, 1964,; Ofosu-Mensah, 2009, and 2014).

It was also the norm to work deep into the night when miners hit rich gold bearing belts. This was purposely to prevent other miner groups from exploiting it at night. The primary intent of these early miners was to quickly recover as much gold as possible before other groups got wind of their location. Mining at night progressed steadily with the aid of locally manufactured baked clay lamps, fastened at the base with palm oil soaked old stripped rags, cloth tags, or wicks.

The basic tool-kits used by native miners at Awudua Dada in the past were all locally designed and manufactured. The common ones comprised pick-axes (asosor), ground hoes, shovels (sosstupre), and hammers. It is noteworthy that though the tools and the technologies employed were simple, they were intriguingly efficient.

In the past, a third of all winnings from mining was first paid to the "stool" as resource rent. Stone and metal weights, and local scales were used to carefully calculate and determine the one-third value. Thereafter, the remainder was sold to established indigenous brokers in the community who also resold to non-resident middlemen from the coast and northern hinterland markets like Begho and Bondoku. Gold served five 
major purposes in the past at Awudua Dada. These included as a trade commodity, store of value, medium of exchange, as major component of chieftaincy regalia, and for body ornamentation (Ofosu-Mensah, 2014, 2017[a]; Addo-Fenning, 1997; Garrard, 1980, 1982; Rodney, 1969; and Dumett, 1998)

Pre-colonial traditional gold mining barely impacted agricultural output in the research area in the past. Aside the small soil heaps and uncovered pits it generated, it also had relatively negligible consequences on aquatic bodies and the natural environment. This was primarily because population levels were low and the technologies employed did not utilize dangerous chemicals such as cyanide and mercury as pertains currently in the study area.

\section{The archaeological research}

A courtesy call on the chief of Awudua, Nana Kwabena Angu 11 and his elders at his palace by the research team preceded the archaeological research. The purpose of the visit was threefold: the first was to present "drinks" as is customary of visitors wanting to meet the chief. The second was to notify them of our intention to conduct archaeological investigations at their ancestral home, and the third was to seek their permission to commence work. Our interaction with the elders was fruitful because the team accomplished all of the above. The elders also delegated a local guide to accompany us to the site to pour libation and to seek "blessings" from their ancestors. The research team comprised the author (Principal Investigator), a Senior Technician, and a graduate student from the Department of Archaeology and Heritage Studies (DAHS), University of Ghana. Two locals from the community were also hired to assist the research team.

Archaeological sites identify where humans have occupied the landscape, and generally contain considerable clusters of material remains such as artifacts, ecofacts and features in varying combinations (Browne, 2017, pp. 31-33; 
Sharer and Ashmore, 2006, pp. 116, 620). The borderlines of most archaeological sites are not well-defined and are established by noting the decline in density and frequency of surface artifact scatters. Most archaeological sites take several millennia to form and the nature and depth of the cultural deposit (stratigraphy) can reveal how long it was occupied. Several processes, natural and man-made oftentimes, work in tandem to create sites. The former include geomorphological occurrences like erosion, deposition and earthquakes. The latter include accumulations of food related wastes like shellfish remains, some socio-cultural and religious practices, and refuse disposal activities of the population that previously settled the site.

The first phase of the archaeological research involved a total of six surface surveys, all undertaken on foot in November, 2019. This period coincides with the dry season in the research area when much of the overlying vegetation has withered and the ground is bereft of its vegetative cover which allowed for optimum observation and collection of overlying cultural materials for laboratory analysis. The first three surface surveys covered the entire area which Nana Kwabena Oboh II, chief linguist (Okyeame) of Awudua, Nana Dasman (Odikro) of Bondaye, and Nana Adu Panyin 11 (chief of Mbease Nsuta) had intimated earlier to the research team was the original settlement quarter of Awudua Dada. The other three surface surveys covered the hilly area around the precincts Fort Ruychaver, approximately 150 metres north of the Ankobra River.

Three "galamseyer" groups, each comprising 6,12 and 8 persons respectively, including three women were observed busily working inside six pits they had opened at different locations at the site. All three groups were armed with rifles and cutlasses and the research team including our local assistant, who was known to them, were questioned extensively as to why we had come there. Our storage bags holding two Global Positioning Systems (G.P.S), a Total Station, measuring tapes, two tents, batteries, a camera, and stationery to take down 
notes were thoroughly searched. Fortunately for us, we had on ourselves our personal University of Ghana identity cards to prove our identities and corroborate our places of work. Our research vehicle, an old Land Rover with "Department of Archaeology and Heritage Studies" inscribed on it and the University of Ghana logo boldly embossed on its two front doors also appeared to have convinced them that we were researchers on a mission to unravel Awudua Dada's historic past. It was after these interventions that our team was allowed to set-up equipment and commence the archaeological excavations. Even then, we were followed around the site for the first two days.

\section{Results of the surface survey}

A large portion of the original settlement quarter of Awudua Dada had been planted with cocoa, interspersed with food crops. The farm however, appeared abandoned because it was overgrown with weeds, several thickets of bamboo (Bambusaar undinaria), creepers, and climbers of which Leptaspis cochleata, Olyra latifolia and Cnestis ferrugina D.C were the commonest. The principal tree-types noted across the site included small scatters of immature Neem (Azadirachita indica) Afrormosia elata, Chlorophora excels, Entandrophragma spp, Mimusops heckeli and Khaya spp). The area had a dark humid ambience, the result of the thick three-canopied forest cover which debarred direct entry of sunlight. Using density of surface artifact scatters and a Global Positioning System (GPS), the roughly ovoid circumferential borderlines of the ancient settlement quarter was delineated. Its geographical parameters was estimated at 748.1 square metres (approximately 4.1 hectares). This is relatively expansive for an early seventeenth century settlement and is indicative that the population may have been quite sizable and dense in the past. The settlement was also wider at the southern end than at the northern end.

A dense mat of decomposing leaves measuring approximately 12 centimetres thick, and several scatters of 
rotting tree trunks, all infested with termites also covered much of the settlement area. It is imperative to note that none of the latter were found across the areas bordering the occupation zone. The leaves hindered ground visibility and made artifact recovery cumbersome. It was also difficult to identify the tree species mainly because all had decomposed extensively. It was also difficult to speculate from the available evidence how they got there and why so many littered the site. The trunk sizes, shapes and lengths variated and did not conform to any standardized measure. The majority, however, ranged in size from $8-12$ centimetres diametrically, and 1.5-5.4 metres in length. According to the "galamseyers found prospecting for gold at the site, the short ones were used as buttresses to support the lateral roofs and sides of the pits, to prevent them from caving, while the long ones served as hoisting pulleys to haul calabash holding gold-bearing soils to the surface. Their straight and smooth-edged ends, suggests that a sharp-cutting device, similar to an axe may have used to deliberately fell them.

It is worth noting that all the 71 heaps of soil discovered at the site contained veritable mixes of varieties of cultural materials such as potsherds, fragments of alcoholic beverage bottles (fig. 2), "S" shaped red roofing slates, daub (some of which appeared to be burnt), and thousands of small angularly-shaped soft rocks of no identifiable shape or size measuring about 6 centimetres across their longest axis. Shellfish remains, bones belonging to a variety of animals, and metal objects constituted other notable contents in the soil heaps. Erosion had exposed these materials, many of which could be seen partly embedded along the sides of the soil heaps. The types and quantum of cultural materials retrieved during the surface surveys are presented below in Table 1.

A total count of 102 recently opened, and old partlycovered gold prospecting pits and trenches not back-filled by the miners were noted overlying much of the ancient settlement quarter (Fig. 3). Each pit averagely measured only 1.6 metres 
from the other, and their high count bears testimony to the economic primacy of gold mining at Awudua Dada in the past. A total of 73 out of the lot were filled-up, almost to ground surface, which suggest they were probably older, compared to the other 29 which were only filled-up midway. The majority of the pits were roughly circular in shape, with average diameters of 0.762 metres across their longest axis. This would have allowed just about one person to conveniently work the base and lateral surroundings of the pit at a time. The trenches, however, were wider with average diameters of about 1.372 metres across their longest axis which would have comfortably permitted two persons to work them in tandem. It was not possible to guesstimate the depths of the pits and trenches because all had significant depositions of up-cast earth, most likely the result of erosion, facilitated by the frequent downpours experienced at the research area.

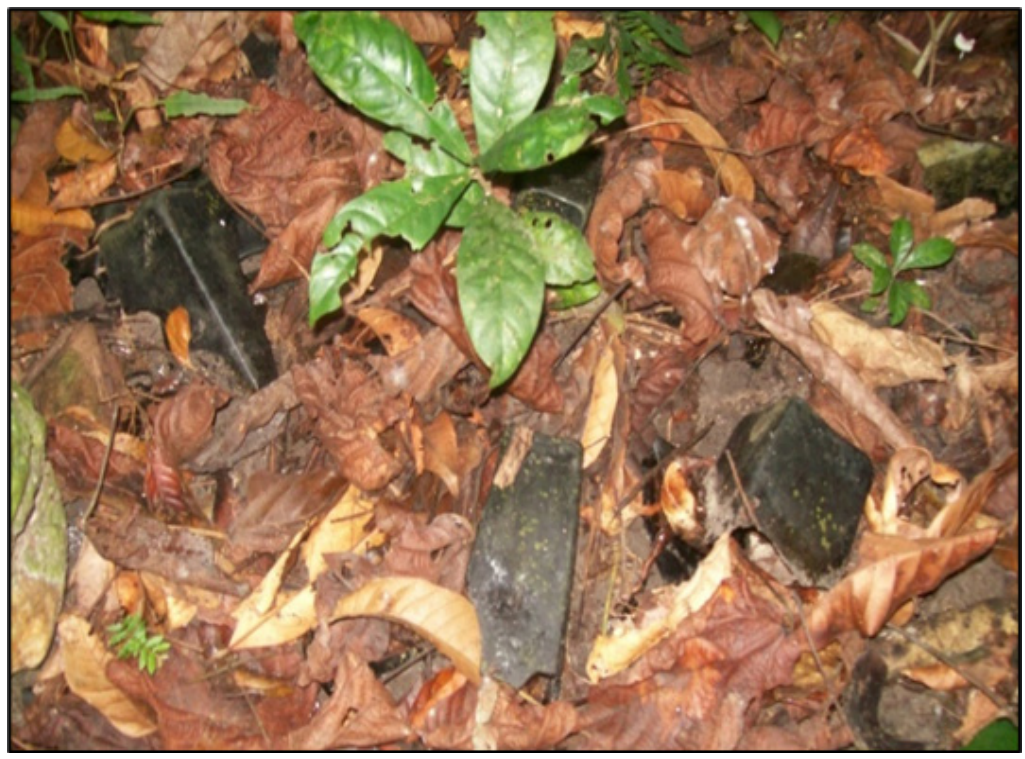

Fig 2. Displaced fragmented bottles overlying the site (Photo: Author) 


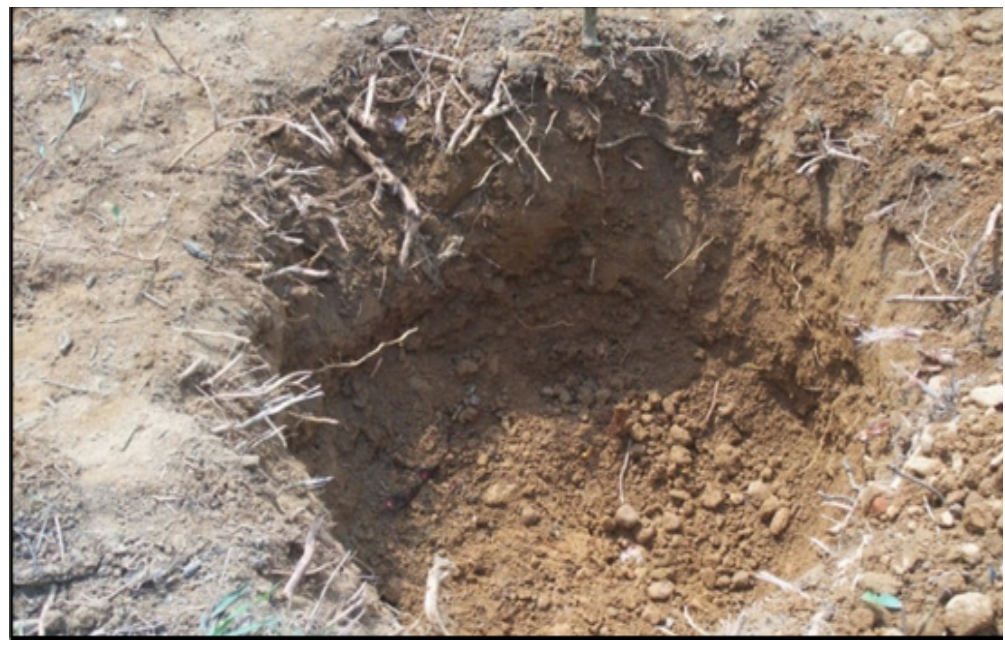

Fig. 3. One of several partly covered ancient gold prospecting pits at Awudua Dada (Photo: Author)

Aside the cultural materials and soil heaps, 31 low-lying mounds were also noted across the ancient occupation zone. The mounds had no identifiable shape or size but were generally more elongated along one side. Averagely, each lay approximately 5 metres at the most from the other which suggests that the past settlement pattern may have been dense and convoluted. The mounds appeared to be the collapsed wattle and daub houses of the previous settlers. Another notable observation were the several scatters of newly stratified matrices, formed out of the old, redeposited soil heaps. Like the newly heaped soils, heavy rains which are a regular occurrence in the region had partly exposed several embedded cultural materials across the occupation grounds.

About 27 metres east of the original settlement quarter, two small "galamseyer" groups of three persons each were observed panning gold in the Ankobra River (Fig. 4). A larger group numbering 11 persons were also found using a heavy- 
duty excavator to divert the natural course of the Ankobra River to allow recovery of gold bearing rocks from the riverbed (Fig. 5). Their activities had negatively degraded the environment, exposing and sun-drying large sections of the riverbed (Fig. 6). Further exacerbating degradation were the several large soil heaps harvested from the riverbed which had been recklessly dumped on either banks of the river. During downpours, significant portions washed back into the river, raising the riverbed and adversely flooding nearby farmlands.

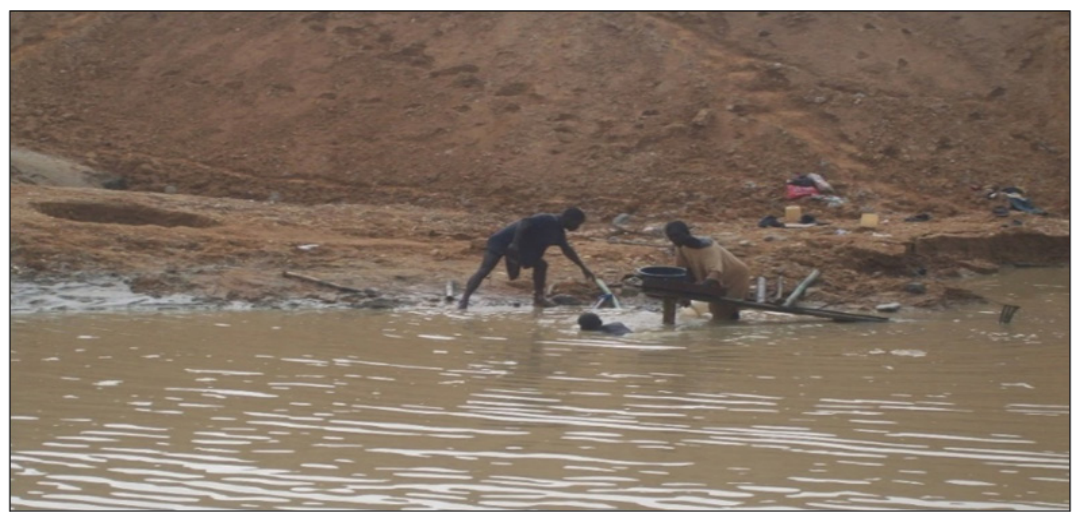

Fig. 4. Panning for gold in the Ankobra River (Photo: Author)

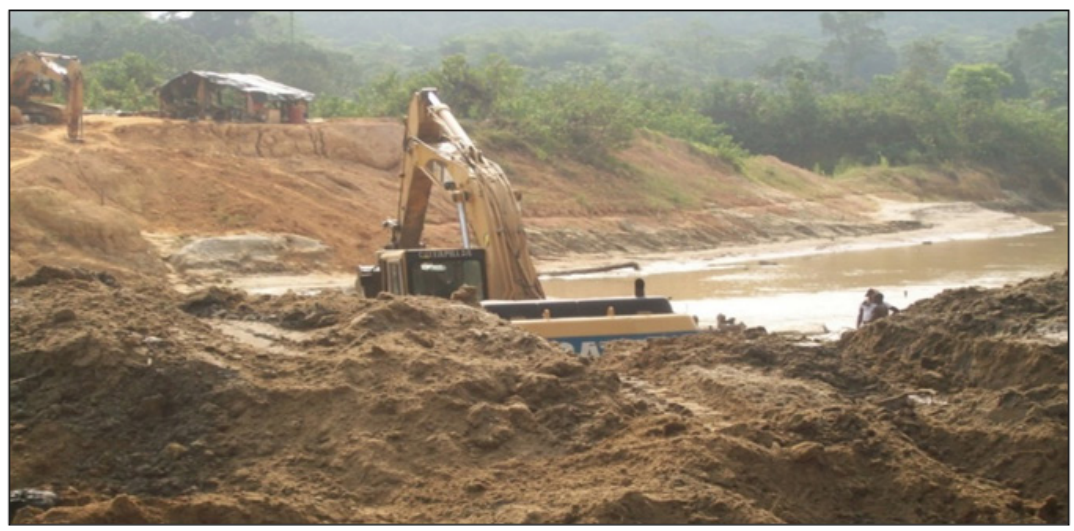

Fig 5. An excavator diverting the natural flow-path of the Ankobra River (Photo: Author) 


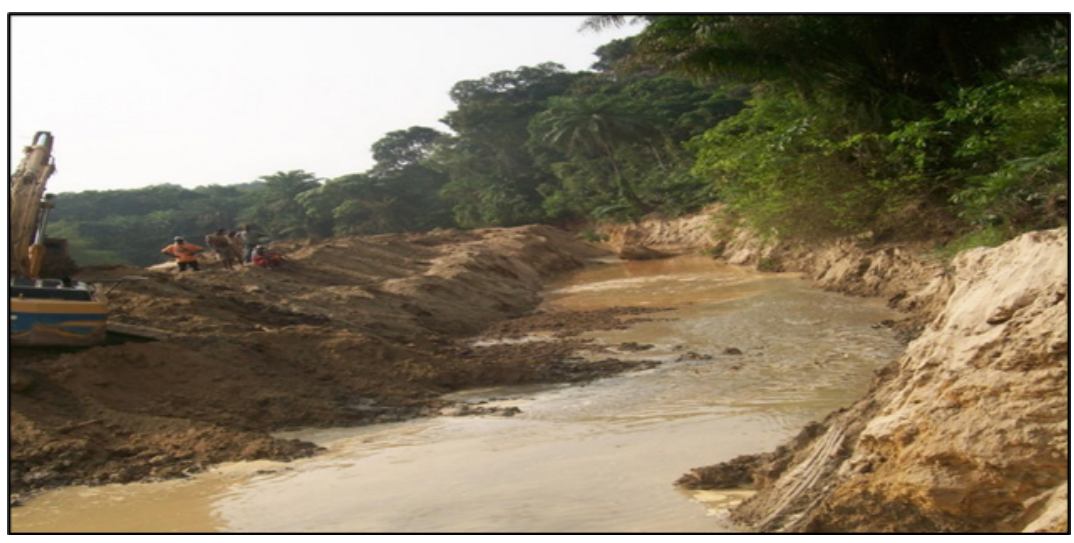

Fig. 6. One of the newly created diversionary paths on the Ankobra River, to allow for gold prospecting on the river bed (Photo: Author)

Fragmented green and white alcoholic beverage bottles dominated the glass assemblage overlying the site's surface. The bulk appeared to be schnapps and gin holding containers. Another notable observation was that a total of 276 of the assemblage (representing 84\%) were densely covered with patches of patina on their interior and exterior surfaces. Patination on glass and flint artifacts are primarily the result of chemical alteration and/or extensive exposure to vagaries of tropical weather conditions, and their count and the patination density detected is oftentimes assumed to be a function of time. Many archaeologists thus, use it as a rough guide to determine the relative ages of artifacts (Sharer and Ashmore, 2006, p. 317). It is germane to note that while the ends and edges of some of the bottle fragments appeared to have been recently fractured, exemplified by their fresh brightly coloured sharp edges, others had blunted edges with dull darker colourations. This can be considered as evidence that the latter were the older of the two. The large numbers of fractured bottles at the site were probably a consequence of the regular use of hardy metal tools by the miners to break ground. 
Like the ancient occupation area of Awudua Dada, the natural stratigraphy underlying the precincts of Fort Ruychaver and its neighbourhoods atop the hill had also been extensively disturbed by farming activities of the people. Except for several scatters of fragmented "S" shaped red roofing slates overlying the ground surface, and two large stone piles, much of the area was bereft of artifacts. The ruined stone foundations of Fort Ruychaver are still visible, aligned in a northeast-southwest direction.

Table 1. Cultural materials collected during the surface surveys

\begin{tabular}{|c|c|c|c|}
\hline \multicolumn{4}{|c|}{$\begin{array}{c}\text { Material remains collected during the reconnaissance survey at } \\
\text { the ancient settlement quarter of Awudua Dada }\end{array}$} \\
\hline \multicolumn{2}{|r|}{ Type of material remains } & Count & Percentage \\
\hline 1 & Shellfish remains & 16 & $7.5 \%$ \\
\hline 2 & Pottery & 34 & $16.0 \%$ \\
\hline 3 & Red roofing slates & 115 & $54.2 \%$ \\
\hline 4 & Alcoholic beverage bottle fragments & 41 & $19.3 \%$ \\
\hline \multirow[t]{2}{*}{5} & Bones & 6 & $2.8 \%$ \\
\hline & Total & 212 & $100 \%$ \\
\hline \multicolumn{4}{|c|}{$\begin{array}{l}\text { Material remains collected during the reconnaissance survey at } \\
\text { Fort Ruychaver }\end{array}$} \\
\hline & Type of material remains & Count & $\begin{array}{l}\text { Percentage } \\
\text { values }\end{array}$ \\
\hline 1 & Red roofing slates & 9 & $0.5 \%$ \\
\hline 2 & Alcoholic beverage bottle fragments & 1,611 & $99.0 \%$ \\
\hline \multirow[t]{2}{*}{3} & Pottery & 7 & $0.4 \%$ \\
\hline & Total & 1,627 & $100 \%$ \\
\hline
\end{tabular}

The excavation of three units designated Units 1, 2, and 3 by the author at different locations across the research area followed the surface surveys and constituted Phase 2 of the 
archaeological investigations. Units 1 overlay a mound believed to be a collapsed house. The area incorporating Unit 2 appeared to be undisturbed by miner activity, evidenced by the thick vegetative cover overlying it and the dense scatter of cultural materials found there. Unit 3 was located 13 metres north-west of Fort Ruychaver. Each unit measured 1 by 2 metres, and the sterile levels for Units 1 and 2 were 140 centimeters below ground surface, while that for Unit 3 was 100 centimeters below ground surface. The types of cultural materials retrieved from the three units and their count are shown in Tables 2, 3 and 4 below.

Table 2. The types and count of cultural materials retrieved from Unit 1

\begin{tabular}{|l|l|r|r|r|r|r|r|r|r|}
\hline \multicolumn{2}{|c|}{ Types of cultural materials } & Level 1 & Level 2 & Level 3 & Level 4 & Level 5 & Level 6 & Level 7 & Total \\
\hline 1 & Shellfish remains & 7 & 3 & 11 & 9 & 3 & 4 & 5 & 42 \\
\hline 2 & Pottery & 29 & 27 & 41 & 36 & 27 & 19 & 7 & 186 \\
\hline 3 & Bones & 8 & 21 & 11 & 14 & 9 & 11 & 4 & 78 \\
\hline 4 & Red roofing slate & 11 & 24 & 19 & 26 & 31 & - & - & 111 \\
\hline 5 & Alcoholic beverage bottles & 19 & 37 & 28 & 11 & 3 & - & - & 98 \\
\hline 6 & Daub & 2 & 4 & 1 & 2 & - & - & - & 9 \\
\hline \multicolumn{2}{|c|}{ Total } & 70 & 96 & 111 & 118 & 79 & 34 & 16 & 524 \\
\hline
\end{tabular}


Table 3. The types and count of cultural materials retrieved from Unit 2

\begin{tabular}{|c|c|c|c|c|c|c|c|c|c|}
\hline \multicolumn{2}{|r|}{ Types of cultural materials } & Level 1 & Level 2 & Level 3 & Level 4 & Level & Unit 6 & Level 7 & Total \\
\hline 1 & Shellfish remains & 2 & 7 & 9 & 4 & 2 & 4 & 1 & 29 \\
\hline 2 & Pottery & 13 & 33 & 38 & 29 & 17 & 21 & 7 & 158 \\
\hline 3 & Bones & 4 & 13 & 11 & 7 & 6 & 7 & 3 & 51 \\
\hline 4 & Red roofing slate & 7 & 4 & 17 & 13 & 21 & - & - & 62 \\
\hline 5 & Alcoholic beverage bottles & 51 & 29 & 21 & 13 & 1 & - & - & 115 \\
\hline 6 & Kaolin smoking pipes & - & - & 1 & - & 1 & - & - & 2 \\
\hline & Total & 47 & 76 & 97 & 96 & 58 & 32 & 11 & 417 \\
\hline
\end{tabular}

Table 4. The types and count of cultural materials retrieved from Unit 3

\begin{tabular}{|r|c|r|r|r|r|r|r|}
\hline \multicolumn{2}{|c|}{ Types of cultural materials } & Unit 1 & Unit 2 & Unit 3 & Unit 4 & Unit 5 & Total \\
\hline 1 & Pottery & 47 & 49 & 13 & 22 & 139 \\
\hline 2 & Red roofing slate & 6 & 13 & 6 & 2 & - \\
\hline 3 & Alcoholic beverage bottles & 5 & 13 & 7 & 11 & - \\
\hline & Total & 58 & 75 & 26 & 35 & 8 & 202 \\
\hline
\end{tabular}




\section{Analysis of the archaeological data}

Local pottery and fragmented alcoholic beverage bottles constituted the most ubiquitous cultural materials recovered from the Awudua Dada excavations and represented $42 \%(\mathrm{~N}=$ $483)$ and $21 \%(\mathrm{~N}=249)$ respectively of total cultural materials discovered. The exteriors and interiors of the potsherds appeared well-worn and lusterless, and averagely measured only 5-10 centimeters across their longest axis. Reconstruction of the mouth, necks and shoulders of the vessels indicated that the majority were bowls of which five types were identified and designated Bowl Types 1, 2, 3, 4, and 5. A total of 10 sherds randomly selected from both surface and excavation contexts were selected for petrographic analysis at the Department of Earth Sciences Laboratory, University of Ghana, Legon and revealed that hornblende, phyllites, and quartz constituted their principal mineral constituents.

The bulk of the glassware assemblage appeared to be schnapps and gin bottles, and comprised parts such as the mouth $((\mathrm{N}=22,9 \%)$, the main body $(\mathrm{N}=194,78 \%)$, neck $(\mathrm{N}$ $=9,4 \%)$, shoulder $(6 \%)$ and bases $(3 \%)$. The remainder $(\mathrm{N}=$ $24,9 \%$ ) were designated undiagnostic because they were too small to facilitate reconstruction. They measured less than one centimeter across their longest axis. A mirror pane and one square-based bottle with squared-off shoulders, measuring 2.5 centimeters from top to base, and believed to be a pomade or pharmaceutical holding suppository constituted the only nonbeverage glassware items found. The shapes and colourations of the bottles varied. The majority of the schnapps bottles were dark green in colour and had rectangular bodies, square-shaped bases, squared-off shoulders, and short stubby necks. The bulk of the gin bottles were white in colour with a few having light green colourations. It was not possible to establish the ages, the production distillery and country of origin because the majority were unmarked. Aside over $79 \%(\mathrm{~N}=196)$ measuring less than $3^{2}$ centimeters across their longest axis, several were also heavily 
patinated further making identification difficult.

It is worth noting that though early Dutch sources averred that trade was the raison d'etre for the Dutch presence at Awudua Dada, the archaeological evidence indicated otherwise. This is because the bulk of the alcoholic beverage bottles were found at stratigraphy levels that corresponded to the latenineteenth to early-twentieth century era, which long post-dated the Dutch occupation period of 1654-1659. The large quantum of alcoholic beverage bottles discovered is overwhelming testimony that European liquor was in high demand during that period. It probably constituted an integral import commodity to the research area in the past.

A total of 1,627 partially-burnt fragmented "S" shaped roofing slates, and 9 pieces of daub constituted the only cultural materials associated with building and construction found at Awudua Dada. The relatively wide scatter of the former, averaging about 27 fragmented pieces per square metre across the entire settlement perimeter of Awudua Dada, coupled with the fact that the bulk were blackened and burnt is ample evidence that Fort Ruychaver indeed went up via an explosion as was reported in early Dutch records (Dantzig 1973: 169-185, Lee 1835: 139-144)). Only 2 well-burnished stems of kaolin smoking pipes measuring 1.9 and 2.3 centimetres long respectively were recovered. It was not possible to identify the manufacturer/s and country of origin because all were unmarked.

Other notable cultural constituents retrieved from the excavations comprised bones of varieties of mammalian species and shellfish remains. Except for 1 each of humerus and phalanges identified as belonging to domesticated goat (Capra), the remainder were too small with no established reference marks to facilitate identification of the body part/species. The remains of 72 molluscs identified as Thais haemastoma, $(\mathrm{N}=$ 52) and Turretila meta $(\mathrm{N}=20)$ constituted the only shellfish species found. The former is a terrestrial molluscs adapted to humid forest habitats while the latter is a freshwater specie. 


\section{Discussion}

Centuries of small-scale miner activities at Awudua Dada had not only negatively impacted the physical environment and natural flow path of the Ankobra River but had also displaced significant quanta of cultural materials from their original contexts in the archaeological record. Context is defined as characteristics of archaeological data that result from combined behavioural and transformational processes, evaluated by means of recorded association, matrix, and provenience (Sharer \& Ashmore 2006: 610). There are two types of contexts. The first type called primary context refers to conditions where the provenience, association, and matrix have not been disturbed by human, tectonic, and other natural forces from the time the artifacts were first deposited, up to the time when it is discovered. The second type is called secondary context and refers to conditions where the provenience, association, and matrix have been wholly or partly disturbed by human, tectonic and other natural forces. The wide scatters/clusters of cultural materials, wholly and partly exposed in heaps of soil (Fig. 3) overlying the ancient occupation quarter is indication that the latter type applied to the study area.

Analysis of archaeological data in their primary context is central in all archaeological investigations and has aided archaeologists interpret/reconstruct the socio-economic and cultural past of ancient societies. In Ghana and elsewhere in the sub-region, it has helped shed significant light on notable ancient traditions like the Kintampo Complex (circa, 2500 2,000 B.C.), and the early phase of the Euro-African encounter (1471-1550). The cultural materials discovered at Awudua Dada, had they been found in their primary contexts could have facilitated socio-cultural reconstruction of past life-ways of the indigenous population which settled the site prior to the Dutch arrival. The short Dutch-Wassa commercial interactive period (1654-1659), the Janty-Jan de Liefde battle of 1659 are other events/occurrences which could also have been reconstructed. 
Equally germane for reconstructing the human past is the scientific study of undisturbed archaeological deposits (strata). Stratification occurs everywhere, at both human and non-human occupation areas, and refers to the multiple strata whose order of deposition reflects the geological Law of Superposition. The concept of stratification is the primary means of demonstrating the positions of cultural assemblages relative to each other, and without a clear understanding of strata and how they were formed, all attempts at accurately establishing degrees of association of artifacts will be frustrated.

Strata are formed principally through natural transformational agencies and human behavioural processes. The former occurs when windstorms, moving ice, and floodwaters overrun a wide area and deposit small pebbles, alluvium, and other laded materials on the ground. The latter occurs when everyday human occupational activities like trash dumping at community middens/refuse disposal sites generate layered formations over time. Though not always well-defined, the individual stratum of archaeological deposits is oftentimes, easily discernible because they present in varieties of colours, textures, and compositions. They can also appear sloping or roughly horizontally-layered, and in thin or thick formations.

The scientific study of strata are useful in two ways. The first is that it facilitates chronological sequencing of the various layers and their cultural contents at archaeological sites because the depositional sequence of the observable layered matrices (including their inherent material contents), from the base to the top, reflect the order of deposition (Browne, 1978, pp. 20-24). The second is that it has aided archaeologists and palaeontologists reconstruct paleo-ecological and environmental conditions globally. At the settlement quarter of Awudua Dada, centuries of mining and other human activities had displaced lower strata with their cultural contents from their original placement levels in the stratigraphy (primary context) to the upper levels of the stratigraphy and ground surface making 
chronological/temporal sequencing, and cultural reconstruction of past life-ways impossible.

The study of undisturbed strata can also facilitate dating of some cultural materials by association. Association is defined as "the occurrence of an item of archaeological data adjacent to another and in or on the same matrix" (Sharer and Ashmore, 2006, p. 608). Dating by association is possible when the age of one cultural item in the stratum is known absolutely, it can be postulated that other cultural items in that stratum date to that period/time.

\section{Conclusion}

Several decades of using crude and unregulated hardy tools by small-scale artisanal gold miners at Awudua Dada had significantly displaced and destroyed the bulk of the site's archaeological data and other heritage resources, the most notable being the stone foundations of Fort Ruychaver. Their operations had also physically degraded large portions of the settlement area by depleting the settlement's forest cover and disrupted local livelihoods of the locals. Other notable consequences of their illicit activities include the rendering of large tracts of otherwise fertile cultivable topsoil unusable. Prior to their relocation to Awudua, agriculture was the lynch-pin and lead growth-driver of the local economy. Its current potential contribution to socioeconomic growth and development is largely under-exploited.

The Prestia-Huni Valley District Assembly which has political/administrative jurisdiction of Awudua Dada and its neighbourhoods should in the short-term initiate programmes to educate "galamseyers" on the harmful effects of the chemicals and new technological innovations they are currently utilizing to win gold in the district. The Inspectorate Division of the Assembly as a matter of urgency also needs to strengthen and enforce its by-laws to enable effective control of the smallscale mining sector to curtail the ubiquitous environmental and occupational safety problems "galamseyers" are causing there. 
In the long term, I can also develop initiatives around the ruined foundations of Fort Ruychaver to make the area part of Ghana's burgeoning tourist infrastructure, similar to what the locals of Assin Manso have done, constructing a memorial garden and a "Wall of Remembrance" of what used to be a "slave" transit/ refreshment camp. 


\section{References}

Addo-Fenning, R. (1997). Akyem Abuakwa 1703-1943 from Ofori Panin to Sir Ofori Atta. Trondheim: Norwegian University of Science and Technology.

Agbesinyale, P. (2003). Ghana's Gold Rush and Resource Development. Dortmund: Spring Research Series.

Amankwa, R. K., and Sackey C. A. (2003). Strategies for sustainable

Development of the small-scale Gold and Diamond-

Mining Industry of Ghana. Resources Policy (29) (Pp131-38)

Anquandah, J. (1999). Castles and Forts of Ghana. Paris. Atlante.

Anquandah, J. (1982). Rediscovering Ghana's Past. London. Longman.

Arhin, K. (1978). Gold mining and Trading among the Ashanti of Ghana. Journal des Africanites. 48. (Pp80-100)

Boahen, A. (1980). Topics in West African History. London. Longman.

Barbot, J. (1732). A Description of the Coast of North and South Guinea. Churchills Collection of Voyages and Travels. Vol. 5. A. Churchill. (Ed.) London. (Barbot's own translation of his original French texts, written in 1680's and published posthumously).

Bosman, W. (1705). A New and Accurate Description of the Coast of Guinea. London. Frank Cass Ltd.

Brown, D. (2017). Principle and Practice in Modern Archaeology. London. Hodder and Stoughton

Burton, Captain R. F. (1863). Wandering in West Africa. London. Tinsley Brothers.

Burton, Captain R. F. and Cameron, L. V. (1883). To the Gold Coast for Gold. London. Chatto \& Windus.

Claridge, W. W. (1972). The Gold Coast and Ashanti. Vol. 1. New York. Barnes and Noble Inc.

Daaku, K. Y. (1970). Trade and Politics on the Gold Coast 1600 - 1720: A Study of the African Reaction to European Trade. Oxford. Clarendon Press

Dantzig, van A. (1973). The Dutch and the Guinea Coast 16741742: A Collection of Documents from the General Sate Archives The Hague. Accra. Ghana Academy of Arts and Sciences.

Dantzig, A. van. (1980). Forts and Castles of Ghana. Accra. Sedco Publishing Limited.

Delpino, G. (2013). The Trade, the Gold and the Ankobra River: Anthropological Research around Fort Duma, Fort Ruychaver, Fort Batenstein and Fort Eliza Carthago Michel Doortmont, Pierluigi Valsecchi and James Anquandah (Eds.). The Ankobra Gold Route: Studies in the Historical Relationship between Western Ghana and the Dutch. Accra. The Ankobra Gold Route Project 
DeCorse, C. R. (2001). An Archaeology of Elmina. Africans and Europeans on the Gold Coast. 1400-1900. Washington. Smithsonian Institution Press.

Doortmont, M. (2013). The Dutch Forts at Axim and Butre: Buildings, People, Politics. The Ankobra Gold Route: Studies in the Historical Relationship between Western Ghana and the Dutch. Michel Doortmont, Pierluigi Valsecchi and James Anquandah (Eds.). Accra. The Ankobra Gold Route Project

Dumett, R. (1998). El Dorado in West Africa: the gold-mining frontier, African labor, and colonial capitalism in the Gold Coast, 18751900. Athens Ohio. James Currey Publishers.

Dumett, R. (1987). Pre-Colonial Gold Mining in Wassa: Innovation, Specialization, linkages to the Economy and the State. Anthropological Papers of the American Museum of Natural History 65(1): (Pp210-224)

Garrard, T. F. (1980). Akan Weights and the Gold Trade. New York Longman. Garrard, T. F. (1982). Myth and Metrology: The Early Trans-Saharan Gold Trade. Journal of African History. (Pp443-461)

Hilson, G. P. (2005). Structural Adjustment and Subsistence Industry: Artisanal Gold Mining in Ghana. Development and Change. 36(1) (Pp103-131)

Lee, R. (1835). Stories of Strange Lands. London. (Pp139-144)

Mantey, J., Owusu-Nimo, F., Nyarko, K. B., and Aubynn, A. (2017).

Operational Dynamics of "Galamsey" within Eleven

Selected Districts of Western Region of Ghana. Journal of Mining and Environment. 8 (1): (Pp11-34)

Ofosu-Mensah, E. A. (2010). Traditional Gold Mining in Adanse. Nordic Journal of African Studies, 19(2), (Pp24-24)

Ofosu-Mensah, E. A. (2011). Historical Overview of Traditional and Modern Gold Mining in Ghana. International Research Journal of Library, Information and Archival Studies, 1(1), 006-022.

Ofosu-Mensah, E. A. (2017[a]). Historical and Modern Artisanal SmallScale Mining in Akyem Abuakwa, Ghana. Africa Today, 64(2), (pp69-91).

Ofosu-Mensah, E. A. (2017[b]) Economic, Social and Political Impact of Mining on Akyem Abuakwa from the Pre-colonial Era up to 1943. Hauppauge, New York: Nova Science Publishers, Inc.,

Posnansky, M. and Dantzig, A. van. (1976). Fort Ruychaver Rediscovered.

Sankofa: The Legon Journal of Archaeological and Historical Studies. (2), (Pp7-16)

Rodney, Walter. (1969). Gold and Slaves on the Gold Coast. Transactions of the Historical Society of Ghana. (10). (Pp13-28)

Romer, R. F. (1964). The Gold Coast of Guinea Part IV "The African History, Customs and Way of Life. Accra. Institute of African Studies. 
Sharer, R. J. and Ashmore, W. (2006). Archaeology: Discovering Our Past. California. Mayfield Publishing Company.

Storsveen, Tove. (2010). Closing the Books: Governor Edward Carstensen on Danish Guinea 1842-50. Accra. Sub-Saharan Publishers Primary Source

Jenkins, Paul. Abstracts of Basel Mission Gold Coast Correspondence. B.V. 3625 G. 5J 41 L.R

Carstensen, E. Gold, Diamonds and Other Minerals, AASA 6/24. 73

\section{Internet Sources}

Zindzy Gracia. (2018). "Causes and effects of galamsey in Ghana”. Yen. com.gh - Ghana news. Retrieved. 2020-01-11.

\section{Personal Communication}

Nana Dasman (Odikro of Bondaye), 2018

Nana Adu Panyin 11 (Chief of Mbease), 2019

Nana Kwaben Oboh 11 (Chief of Awudua) 2019 